\title{
EDUCATIONAL TREATMENT FOR THE MODERATELY HARD \\ OF HEARING IN PRIMARY SCHOOL -A CLASS FOR THE HARD OF HEARING-
}

Part 2. Two Years' Survey of Educational Procedure and its Results in the Class for the Hard of Hearing.

By

NoBuzo NAGAO

From the Department of Oto-Rhino-Laryngology, Okayama University Medical School. (Director: Prof. S. Takahara)

Nineteen handicapped pupils, 15 of sensory-neural and 4 of mixed type hearing loss of $45 \sim 60 \mathrm{db}$, were educated with the use of hearing aids, speechreading and visual educations for the past two years.

The results of the investigations are as follows:

1) Effects of hearing aids and speechreading. The use of hearing aids brought much better im* provement of hearing discrimination in 12 pupils, fairly good in 5 and poor in 2. Combination of speechreading with hearing aids helped more to improve hearing discrimination.

2) Educational achievement. Nine pupils who had two years' education all showed considerable educational progress.
3) Results of speech correction. Seven of 19 pupils showed articulation disorders. Speech correction on them proved to be effective with the use of hearing aids.

4) Intelligence test. Mental ability of pupils were assessed by means of WISC test (modified for Japanese use). Pupils whose I.Q, were below 90, were reluctant to all the special educational procedures mentioned above.

Author concluded that the children who have both an average hearing loss $45 \sim 60 \mathrm{db}$ and the normal intelligence, should be eligible for the class for the hard of hearing.

\section{学童の難聴対策一難聴学級一とその効果}

\section{第 2 編 難聴学級児僮の 2 年間の教育的措置と その成果について}

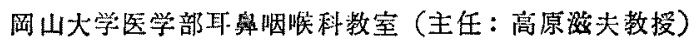

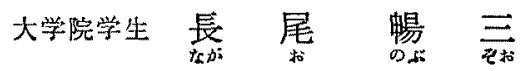

\begin{tabular}{|c|c|c|}
\hline & 次 & 第1章 緒 \\
\hline 䈅 1 音 & 帚 & 昭和 35 年 4 月, 阔山市立内山下小学校に 難聴学除を \\
\hline 第 2 㹁 & 補恥器と就話の效果 & 設立してから2年余を経過し，心理学的に，あるいは補 \\
\hline 符了旅 & 学婪戍絰の向上 & 揌器と読話の効果，学業成績，言語障害の矯正指導なと \\
\hline 籍 4 竟 & 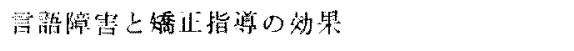 & の上で，難聴学敍というわのの在り方の輸郭をほぼ゙捉え \\
\hline 第 5 学 & 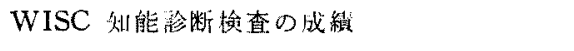 & ることができた，一方，今回の難聴学級昌童の中にはテ \\
\hline 第 6 量 & 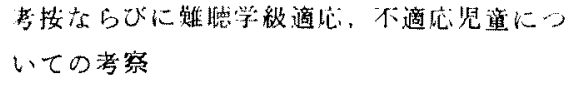 & $\begin{array}{l}\text { ストケースとしてのものも含ま机ていたので，一部の見 } \\
\text { 望では顕著な成果を示さなかつたものもあつた，そこ }\end{array}$ \\
\hline 7 许 & 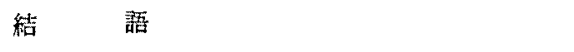 & で，個々の児童について，その成果を考察し，難㯖学級 \\
\hline
\end{tabular}


の適応，不適応という問題を 各方面から改めて検討し た.

\section{第 2 章 補聴器と䛃話の効果}

補聴効果を充分高めるために，補聴器の取扱い，訓練 を特以慎重に指遒した。ワイヤレス集団補㯖器は，ワイ ヤレスと個人用に使い分将ることによつて，複式授業を 行う上で非常に効果的であった。補聴效果が余り期待で きない比較的高度難聴の児童に対しては読話を指導し た，補嵒器と読話の効果を检討するために，難聴学級児 童 16 名々㯖力正常児 5 名を対象に次の検查を行つた。

\section{1 検查語音表}

梌查語音表には、次に示す平易な有意 3 望節語音 50 ケ

第 1 表 梌查語音表 (A)

\begin{tabular}{|c|c|c|c|c|}
\hline サクラ & シロイ & スイカ & オトス & 七ン口 \\
\hline ヤスイ & ソネジ & フシギ & サイフ & $\checkmark ワ$ \\
\hline シブイ & ヒヤス & スウジ & アラシ & $\forall カ$ \\
\hline シカル & センス & アシタ & スゴイ & \\
\hline クスリ & 七力イ & サト才 & アサヒ & \\
\hline$+\Delta 1$ & スズメ & アソビ & ミヒル & $\Rightarrow$ \\
\hline タワシ & スベル & ハヤシ & スルメ & $7 x$ \\
\hline シラガ & スワル & ハシラ & ヤサイ & \\
\hline $1=i$ & ソマッ & シケン & カクス & \\
\hline$E x$ & 水コ久 & ステル & ケムシ & \\
\hline
\end{tabular}

第 2 表 検查語音表（B）

\begin{tabular}{|c|c|c|c|c|}
\hline アオイ & エイガ & オヤッ & イタチ & ケムリ \\
\hline クルマ & カメラ & オナカ & $タ \rightarrow=$ & ב \\
\hline マンオ゙ & ホタル & ヒミ\% & フトン & ナマエ \\
\hline ヌリエ & ネマキ & $=€ \%$ & テレビ & ツミキ \\
\hline キリン & ミルク & $\Delta カ テ ゙$ & メダ力 & ラジォ \\
\hline アター & クウキ & タタミ & オバケ & $カ エ ル$ \\
\hline ホコリ & ハナミ & イナカ & カラダ & タヌキ \\
\hline フヒル & ラクダ & マメリ & マクラ & $=1 x$ \\
\hline カタチ & オトナ & コドーモ & リンゴ & スダマ \\
\hline$=力 1$ & 八tjキ & ミカン & ヘンジ & タンカ \\
\hline
\end{tabular}

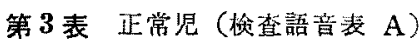

\begin{tabular}{|c|c|c|c|c|c|c|c|}
\hline \multirow[t]{2}{*}{ No. } & & 性 & 䛃 & \multicolumn{2}{|c|}{$\begin{array}{l}\text { 裸 } \\
\text { 年 } \\
\text { phon }\end{array}$} & \multicolumn{2}{|c|}{ 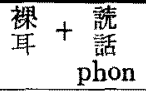 } \\
\hline & 名 & 別 & 話 & 50 & 60 & 50 & 60 \\
\hline 1 & 近 0 & $\delta$ & 10 & 86 & 100 & 96 & 100 \\
\hline 2 & 海 0 & 우 & 12 & 88 & 100 & 96 & 100 \\
\hline 3 & 小 $\bigcirc$ & $\delta$ & 16 & 90 & 100 & 96 & 100 \\
\hline 4 & 0 & 3 & 26 & 92 & 100 & 96 & 100 \\
\hline 5 & 0 & 3 & 20 & 94 & 100 & 98 & 100 \\
\hline & Iy & & 16.8 & 90,0 & 100.0 & 96.4 & $\begin{array}{r}1000 \\
0 \\
0\end{array}$ \\
\hline
\end{tabular}

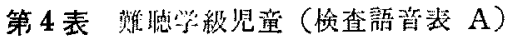

\begin{tabular}{|c|c|c|c|c|c|c|c|c|c|c|c|c|c|}
\hline \multirow[t]{2}{*}{ No. } & & 㜔: & \multicolumn{3}{|c|}{$\begin{array}{l}\frac{\text { 裸 }}{7} \\
\frac{q^{2}}{7}\end{array}$} & hon & \multicolumn{3}{|c|}{ 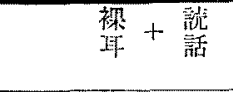 } & Shon & \multirow{2}{*}{ 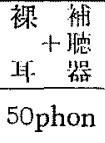 } & \multirow{2}{*}{ 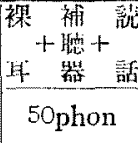 } \\
\hline & & 名 & 獣 & 50 & 60 & 70 & 80 & 50 & 60 & 70 & 80 & & \\
\hline 1 & 尼 & 0 & 46 & 0 & 0 & 16 & 78 & 34 & 40 & 48 & 78 & 84 & 86 \\
\hline 2 & $\mu$ & 0 & 12 & 0 & 0 & 0 & 0 & 8 & 10 & 24 & 10 & 44 & 52 \\
\hline 3 & 啝 & 0 & 42 & 2 & 4 & 10 & 72 & 48 & 64 & 62 & 88 & 80 & 90 \\
\hline 4 & 岩 & 0 & 48 & 0 & 0 & 6 & 84 & 40 & 36 & 56 & 96 & 96 & 100 \\
\hline 5 & 川 & 0 & 42 & 6 & 26 & 54 & 80 & 54 & 84 & 86 & 88 & 90 & 90 \\
\hline 6 & 高 & 0 & 62 & 0 & 0 & 0 & 0 & 54 & 52 & 60 & 56 & 46 & 66 \\
\hline 7 & 黑 & 0 & 82 & 0 & 2 & 12 & 8 & 100 & 100 & 100 & 100 & 92 & 100 \\
\hline 8 & 率 & 0 & 60 & 0 & 2 & 4 & 36 & 94 & 100 & 80 & 98 & 76 & 98 \\
\hline 9 & 富 & 0 & 28 & 0 & 0 & 48 & 56 & 42 & 38 & 52 & 56 & 56 & 66 \\
\hline 10 & 鳥 & 0 & 40 & 0 & 0 & 0 & 20 & 32 & 22 & 26 & 62 & 82 & 86 \\
\hline 11 & 金 & 0 & 4 & 0 & 0 & 14 & 24 & 0 & 4 & 20 & 30 & 40 & 40 \\
\hline 12 & 大 & 0 & 28 & 2 & 0 & 2 & 34 & 2 & 22 & 32 & 38 & 70 & 74 \\
\hline 13 & 福 & 0 & 42 & 0 & 0 & 4 & 100 & 48 & 64 & 72 & 98 & 92 & 100 \\
\hline 14 & 市 & 0 & 10 & 0 & 0 & 6 & 22 & 8 & 6 & 6 & 30 & 32 & 52 \\
\hline 15 & 松 & 0 & 68 & 0 & 2 & 6 & 32 & 72 & 70 & 66 & 68 & 66 & 86 \\
\hline 16 & 清 & 0 & 42 & 0 & 4 & 26 & 74 & 48 & 60 & 70 & 76 & 58 & 84 \\
\hline 平 & & & 40.0 & 0.6 & 2.5 & 13.0 & 45,0 & 42.8 & 48.3 & 53.8 & 67.0 & 69.0 & 79.40 \\
\hline
\end{tabular}


然用いた，検查語音表（A）は音節中にサ行音を含むも D，検查語音表 (B) はサ行音を含まないるのと乙，そ

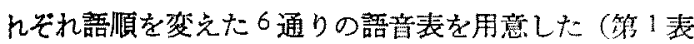
叉び第 2表).

\section{2 梌查方法}

検查は平常授業を行つている難㯖教室で，比較的外部 䖽音の少い時間を選び，担任の男の教師を㭘者とし，検 查語省表を読む声を騷音計で一定の強さになるようにコ ントロールしながら，次の 5 つの場合について行つた。

1）読話のみ；聴賞を全く丹い一方視覚のみによる場合

2）裸耳のみ；視覚も補㯖器も用いず，検者の声を i0，60，70，80phonの4通りの強さにした場合

3) 裸耳と読話の併用; 検者の声を $50,60,70,80$ shonの4通りの強さにした場合

4）裸耳に補聴器を皎用した場合；ワイヤス集団補聴 器を装用し，50phon の検者の声をもつとも良く聴取で きる音量に哑節して聞き，視賞は用いない場合

5）裸耳に補聴器を装用し更に読話を併用した場合 な拉，検査語音の記憶を防ぐために 1 日の検査は数回 ことどめ，次の検查日までに数日の間隔を置くよう考慮 Lた.
3 柃查成績

50ケの桱榃語音のうち正しく答克た割合を正答率とし パーセントで表した（第3表〜第6表）.

ほとえどの児童において，湌查語音表（B）での成績 の方が検查語音表（A）での成績より良い值を示した。

次に，A 表と B 表の各々の場合の成繥を平均しヒ ストグラムにて示した（第1図及び第 2 図）。

B 表での成績について検討すと，読話のみの場合

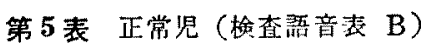

\begin{tabular}{|c|c|c|c|c|c|c|c|c|}
\hline \multirow[t]{2}{*}{ No. } & \multirow{2}{*}{\multicolumn{2}{|c|}{$\begin{array}{l}\text { 氏 } \\
\text { 名 }\end{array}$}} & \multirow{2}{*}{$\begin{array}{l}\text { 珄 } \\
\text { 別 }\end{array}$} & \multirow{2}{*}{$\begin{array}{l}\text { 読 } \\
\text { 話 }\end{array}$} & \multicolumn{2}{|c|}{$\begin{array}{l}\text { 裸 } \\
\text { phon }\end{array}$} & \multicolumn{2}{|c|}{$\begin{array}{c}\text { 裸 }+\begin{array}{c}\text { 梳 } \\
\text { 話 } \\
\text { phon }\end{array} \\
\text { phon }\end{array}$} \\
\hline & & & & & 50 & 60 & 50 & 60 \\
\hline 1 & 近 & 0 & d & 12 & 98 & 98 & 98 & 100 \\
\hline 2 & & 0 & $\delta$ & 16 & 98 & 100 & 94 & 100 \\
\hline 3 & 小 & 0 & f & 26 & 98 & 100 & 98 & 100 \\
\hline 4 & & 0 & $\delta$ & 38 & 100 & 100 & 100 & 100 \\
\hline 5 & 佐 & 0 & t & 26 & 96 & 100 & 98 & 100 \\
\hline & & 均 & & 23.6 & 98.0 & 99.6 & 97.6 & $\begin{array}{r}100.0 \\
(\%)\end{array}$ \\
\hline
\end{tabular}

第 6 表 難聴学粐児童（検查語音表 B)

\begin{tabular}{|c|c|c|c|c|c|c|c|c|c|c|c|c|}
\hline \multirow[t]{2}{*}{ No. } & \multirow{2}{*}{$\begin{array}{l}\text { 氏 } \\
\text { 名 }\end{array}$} & \multirow{2}{*}{$\begin{array}{l}\text { 読 } \\
\text { 話 }\end{array}$} & \multicolumn{4}{|c|}{$\begin{array}{l}\text { 裸 } \\
\text { 耳 }\end{array}$} & \multicolumn{3}{|c|}{ 裸 + 梳 } & phon & \multicolumn{2}{|c|}{ 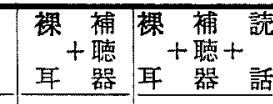 } \\
\hline & & & 50 & 60 & 70 & 80 & 50 & 60 & 70 & 80 & 50phon & 50phon \\
\hline 1 & 尾 $\bigcirc \mathrm{s}$ & 50 & 2 & 4 & 12 & 86 & 50 & 44 & 56 & 88 & 84 & 84 \\
\hline 2 & 山 $\bigcirc \hat{\delta}$ & 26 & 0 & 0 & 0 & 0 & 10 & 50 & 28 & 32 & 74 & 78 \\
\hline 3 & 姝 $\bigcirc 8$ & 48 & 0 & 6 & 4 & 66 & 52 & 58 & 64 & 90 & 86 & 92 \\
\hline 4 & 岩 $\bigcirc \delta$ & 56 & 0 & 0 & 26 & 92 & 66 & 50 & 70 & 98 & 100 & 100 \\
\hline 5 & 川 & 52 & 2 & 28 & 70 & 92 & 64 & 82 & 90 & 96 & 92 & 98 \\
\hline 6 & 高 $\bigcirc \delta$ & 64 & 2 & 2 & 0 & 6 & 66 & 62 & 64 & 72 & 58 & 72 \\
\hline 7 & 黑 $\bigcirc$ q & 70 & 2 & 2 & 8 & 12 & 96 & 100 & 100 & 100 & 74 & 100 \\
\hline 8 & 益 $0 \%$ & 64 & 0 & 10 & 14 & 18 & 92 & 100 & 96 & 100 & 84 & 100 \\
\hline 9 & 富 $\bigcirc 8$ & 32 & 0 & 14 & 58 & 64 & 34 & 54 & 84 & 68 & 82 & 74 \\
\hline 10 & 焦 $\bigcirc 8$ & 36 & o & 0 & 0 & 58 & 38 & 24 & 18 & 72 & 92 & 88 \\
\hline 11 & 金 08 & 6 & 0 & 0 & 24 & 40 & 2 & 12 & 36 & 42 & 46 & 42 \\
\hline 12 & 大 $O \delta$ & 34 & 0 & 2 & 0 & 48 & 4 & 34 & 44 & 58 & 72 & 66 \\
\hline 13 & 福 $\bigcirc 9$ & 52 & 0 & 2 & 6 & 92 & 48 & 64 & 66 & 98 & 96 & 98 \\
\hline 14 & 汸 $\bigcirc$ 今 & 22 & 0 & 0 & 20 & 66 & 18 & 28 & 46 & 66 & 76 & 80 \\
\hline 15 & 㭠 $\bigcirc \delta$ & 78 & 0 & 2 & 14 & 42 & 24 & 76 & 74 & 80 & 78 & 82 \\
\hline 16 & 清 $\bigcirc$ o & 56 & 0 & 8 & 42 & 76 & 58 & 66 & 76 & 86 & 80 & 80 \\
\hline 平 & 均 & 46.6 & 0.5 & 5.0 & 18.6 & 53.6 & 45.1 & 56.5 & 63.3 & 77.9 & 79.6 & $83.4(\%)$ \\
\hline
\end{tabular}


第1图 補聴器と謊話の効果（A表を用いた埸合）

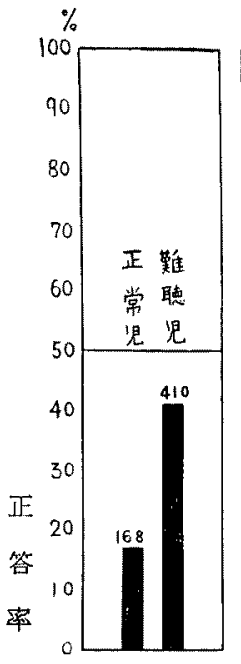

㜔

話

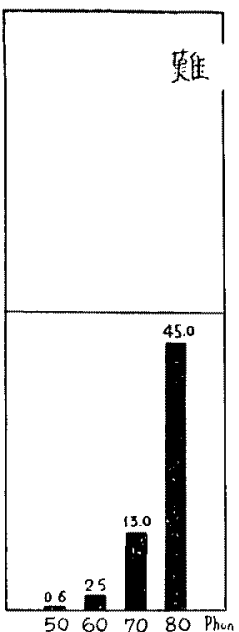

裸

耳

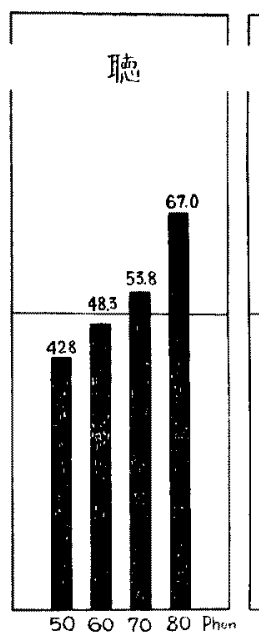

裸 読

耳 $^{+}$話
㷋

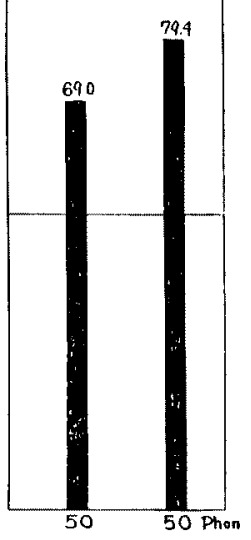

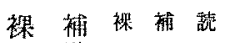

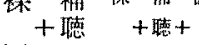

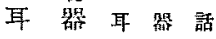

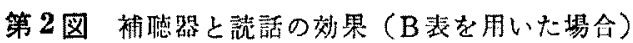

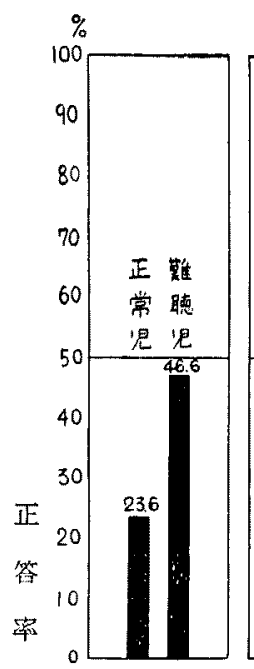

梳

話

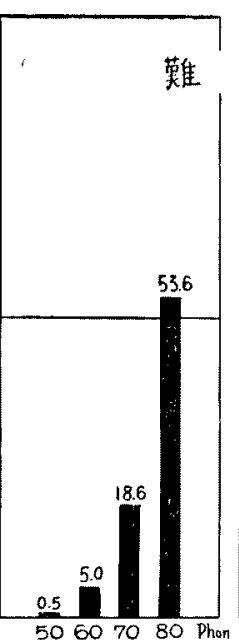

裸

耳-

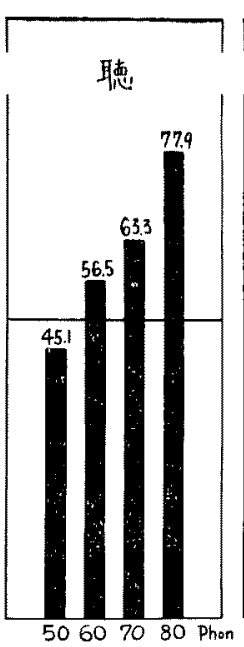

裸 譊

耳 $^{+}$話
况

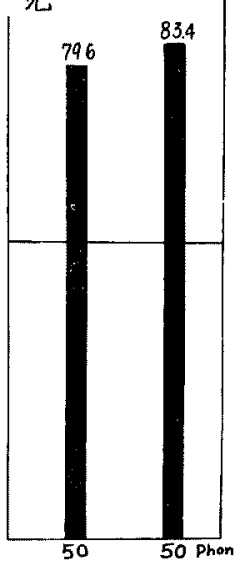

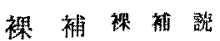

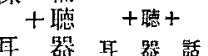

では，正常児 $23.6 \%$ ，難德:学級児童 $46.6 \%$ で，正常児の第 2 倍の正答率 を示した。特に，以前 3 年間万方学 校に在学し，䛃話の 指導を受けて いた No.15 の児童では 78\% を示し t.

裸耳のみの場合，正常児では， 50,60phon でそれぞれ98.0\%，99.6 \%とほとんど 100\% の正答率を示し たが，難聴学級児童では $0.5 \% ， 5.0$ \%を示し，70, 80phonでもそれぞ れ $18.6 \%, 53.6 \%$ の正答率しか示さ なからた。

所が裸耳に読話を併用すると， 80phon で $77.9 \%$ と良い併用效果を 示した。

補聴器のみ戦独使用の場合では $79.6 \%$, 補聴器之読話の併用の場合 では $83.4 \%$ の正答率を示した。

次に，連続周波数による自記オ一 ジオメトリーを行い，果加現象之補 聴効果との関保を検討した。 その絬 果，16 名中 6 名に累加現象を認め，

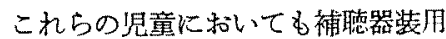
後の正答率は良好であることがわか つた，その2 例を示寸（第 3 图及び 第 4 图)。

第 3 章 学業成續の向上

19 名の児童中既儿 2 年余を絽過 した9名の児童について，入級前と 2 年後の学業成續を比較し，成繹向 上の梯相難聴の程度，補德器によ る補德効果，知能指数の面から检討 した(第子表)。

クラスの児童全体を成結の良い方 か5 10\%, 25\%，50\%，12\%，3\% の制合になるように区分して，10\% 以内にあるものを 5 ，その次の $25 \%$ に含まれるものを4，更にそ机济 く50\%に含まれるものを了，その 次の $12 \%$ に含ま机るものを 2 , 残 りの $3 \%$ を 1 数字で表わした。

全教科の評洒点総計ては，すべて 

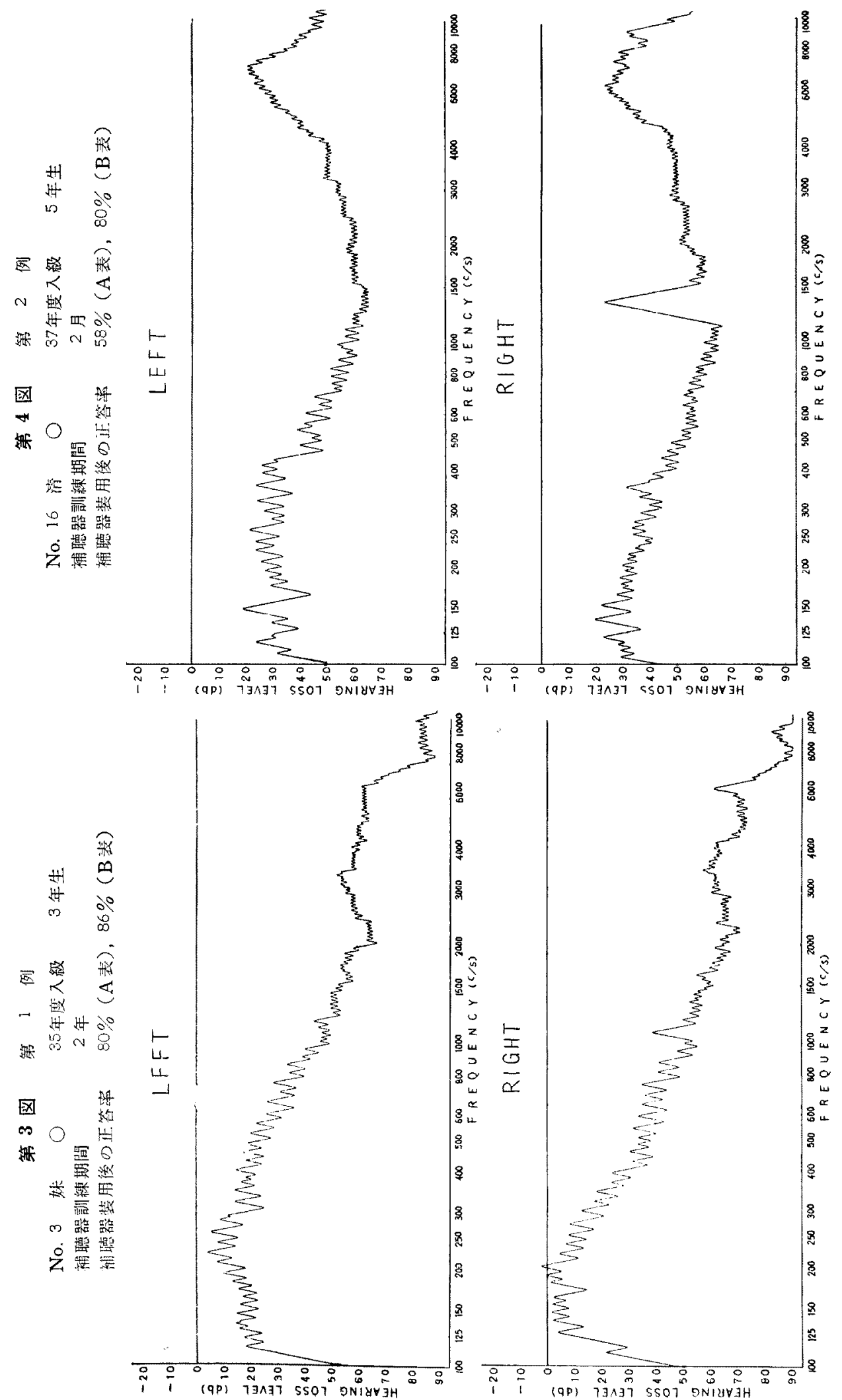


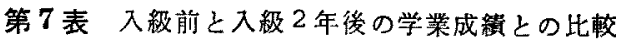

\begin{tabular}{|c|c|c|c|c|c|c|c|c|c|c|c|c|c|c|c|c|c|}
\hline \multirow[t]{2}{*}{ No. } & \multirow{2}{*}{\multicolumn{3}{|c|}{ 氏 }} & \multicolumn{2}{|c|}{$\begin{array}{l}\text { 入 } \\
\text { 級 } \\
\text { 時 } \\
\end{array}$} & \multirow{2}{*}{$\begin{array}{c}\text { I.Q. } \\
\begin{array}{c}\text { I. } \\
\text { 京 } \\
\text { 中 }\end{array}\end{array}$} & \multicolumn{2}{|c|}{ 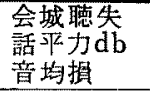 } & \multirow{2}{*}{ 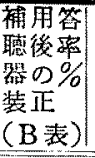 } & \multirow{2}{*}{$\begin{array}{l}\text { 国 } \\
\text { 語 }\end{array}$} & \multirow{2}{*}{$\begin{array}{l}\text { 社 } \\
\text { 会 }\end{array}$} & \multirow{2}{*}{$\begin{array}{l}\text { 算 } \\
\text { 数 }\end{array}$} & \multirow{2}{*}{$\begin{array}{l}\text { 理 } \\
\text { 科 }\end{array}$} & \multirow{2}{*}{$\begin{array}{l}\text { 音 } \\
\text { 楽 }\end{array}$} & \multirow{2}{*}{$\begin{array}{l}\text { 図 } \\
I\end{array}$} & \multirow{2}{*}{$\begin{array}{l}\text { 体 } \\
\text { 育 }\end{array}$} & \multirow{2}{*}{$\begin{array}{l}\text { 話縚 } \\
\text { 做 } \\
\text { 点部 }\end{array}$} \\
\hline & & & & $\begin{array}{l}\text { 年 } \\
\text { 令 }\end{array}$ & $\begin{array}{l}\text { 学 } \\
\text { 年 }\end{array}$ & & 右 & 左 & & & & & & & & & \\
\hline \multirow[t]{2}{*}{1} & & \multirow{2}{*}{0} & \multirow{2}{*}{$\delta$} & \multirow[t]{2}{*}{7} & \multirow[t]{2}{*}{2} & \multirow[t]{2}{*}{102} & \multirow{2}{*}{$90 !$} & \multirow[t]{2}{*}{48} & \multirow[t]{2}{*}{84} & 3 & 3 & 3 & 3 & 1 & 2 & 2 & 17 \\
\hline & & & & & & & & & & 4 & 3 & 4 & 4 & 2 & 3 & 2 & 22 \\
\hline \multirow{2}{*}{2} & \multirow{2}{*}{111} & \multirow{2}{*}{0} & \multirow{2}{*}{ 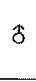 } & \multirow{2}{*}{7} & \multirow{2}{*}{2} & 94 & 57 & 55 & 78 & 1 & 1 & 1 & 1 & 1 & 2 & 3 & 10 \\
\hline & & & & & & & & & 70 & 2 & 1 & 1 & 2 & 1 & 2 & 4 & 13 \\
\hline 3 & 妹 & 0 & S & 8 & 3 & 113 & 57 & 57 & 92 & 3 & 3 & 3 & 3 & 3 & 3 & 3 & 21 \\
\hline & & & & & & & & & & 4 & 4 & 4 & 4 & 2 & 4 & 3 & 25 \\
\hline 4 & \pm & 0 & 8 & 9 & 4 & 118 & 38 & 37 & 100 & 1 & 1 & 3 & 2 & 2 & 1 & 2 & 12 \\
\hline & & & & & & & & & & 3 & 4 & 4 & 3 & 2 & 3 & 3 & 22 \\
\hline 5 & 111 & & $\uparrow$ & 10 & 4 & 122 & 50 & 73 & 98 & 4 & 4 & 5 & 3 & 2 & 3 & 1 & 22 \\
\hline & $n$ & $\circlearrowleft$ & $\delta$ & 10 & 4 & 122 & 50 & 10 & 90 & 4 & 4 & 4 & 4 & 3 & 5 & 3 & 27 \\
\hline 6 & 裔 & $\Omega$ & 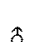 & 10 & 4 & 115 & 85 & 73 & 72 & 1 & 2 & 1 & 1 & 1 & 2 & 3 & 11 \\
\hline & & $\checkmark$ & 0 & & & & & & & 2 & 3 & 2 & 2 & 2 & 4 & 4 & 19 \\
\hline 7 & 诉 & 0 & 8 & 9 & 4 & 117 & 55 & 55 & 100 & 4 & 3 & 4 & 4 & 3 & 3 & 4 & 25 \\
\hline & & $U$ & 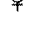 & & 4 & 118 & & (3) & 100 & 4 & 4 & 4 & 4 & 3 & 3 & 4 & 26 \\
\hline 8 & 䨘 & 0 & 8 & 9 & 4 & 103 & 47 & 55 & 100 & 3 & 2 & 3 & 2 & 3 & 2 & 3 & 18 \\
\hline & & 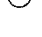 & ${ }^{\ddagger}$ & & & & & & & 3 & 3 & 3 & 2 & 3 & 2 & 3 & 19 \\
\hline 9 & 益 & 0 & 우 & 9 & 4 & 100 & 58 & 58 & 100 & 2 & 1 & 2 & 1 & 2 & 2 & 1 & 11 \\
\hline & & 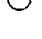 & & & & & & & & 3 & 2 & 3 & 3 & 2 & 3 & 3 & 19 \\
\hline & & & 平 & & & & 均 & & & $\frac{2.4}{3 .} \frac{4}{2}$ & $\frac{3.2}{3.1}$ & $\frac{2.8}{3.2}$ & $\frac{2.2}{3.1}$ & $\frac{2.0}{2.2}$ & $\frac{2.2}{3.2}$ & $\frac{2.4}{3.2}$ & $\frac{16.3}{21.3}$ \\
\hline
\end{tabular}

（上段は入趿前，下段は入趿 2 年後の成綨）

の児童に向上を認め，平均 5 (つまり 16.3/21.3) の向上 を示した． 2 年後の評価点総計の平均 21.3 は一般学級 に扩不均以上の成績であり，成果が充分発押された ものとみてよい，しかし，個々の胃童についてみると， No. 2，6，8，9 の児童の上5に平均㒓せず成續が芳ば しくないものもあつた．この原因について考察を加えて みると，No. 2 の昌童は I.Q. が比較的低いことと補聴 効果が悪いこと, No. 8 と9の罗童は I.Q. が比較的低 いことが原因であつたと考えられる。

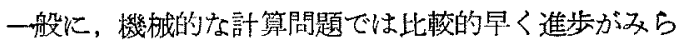
れたが，読解力を必要とする問題では進歩が遅く、この 面での指導が重要であると考えさせられだ。

\section{第 4 章 言語障害と矯正指導の効果}

難聴学級罗童 19 名の言語障害及び矯正指導の効果を， 難聴の程度, 難聴型, 聴力型, 難聴発現年令, 補聴器に 上る補聴効果の面から検討した (第 8 表).

19 名中 12 名核言語障害を認め，そのらち5名は+行
音中の 1 ないし 2 音の構音障害がある比較的軽度，7名 はそれ以上の音に構音障害がある比較的高度のむのであ つた．高度障害 7 名中 3 名は㯖力損失 $60 \mathrm{db}$ 以上の高度 の難聴であり，6名は言語の発達のもつとも盛んな 4 才 までに難聴の発現をみている. No. 2, 6, 14, 18 の児童 にはろう児様の単調な音声を認め，入級以前 3 年間万う 学校教育を受けた No. 18 の見童では聴力に比して特に 著明であつた。

矯正指導は，軽度のものに刘しては授業中にその都度 行い，高度のものに対しては特に時間を設けろう学校の 専門教師が行つた，又，補聴器を補助的手段として用い た。個々の発音指導と同時に，児童が積極的に話せるよ らな明るい雾团気をつくるように心掛け，言語の理解， 語軍の增加, 助詞の使い方，アクセント，抑揚など文章 の作り方，読み方についても指導した，又，児童に毎日 日記を書せ，それを発表させて言語の倸りを互いに指 適，短正させ合う方法をも用いた。 


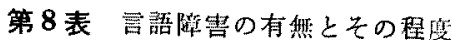

\begin{tabular}{|c|c|c|c|c|c|c|c|c|c|c|}
\hline \multirow[t]{2}{*}{ No. } & \multirow[t]{2}{*}{ 划 } & \multirow[t]{2}{*}{ 名 } & \multirow[t]{2}{*}{ I.Q. } & \multicolumn{2}{|c|}{$\begin{array}{l}\lambda \\
\text { 粐 } \\
\text { 時 }\end{array}$} & \multicolumn{2}{|c|}{ 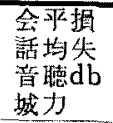 } & \multirow{2}{*}{$\begin{array}{l}\text { 惪 } \\
\text { 力 } \\
\text { 型 }\end{array}$} & \multirow{2}{*}{$\begin{array}{l}\text { 難年 } \\
\text { 聪 } \\
\text { 発 } \\
\text { 現合 }\end{array}$} & \multirow{2}{*}{$\begin{array}{l}\text { 䈏 } \\
\text { 語 } \\
\text { 帟 } \\
\text { 害 }\end{array}$} \\
\hline & & & & 年 & $\begin{array}{l}\text { 等 } \\
\text { 年 }\end{array}$ & 右 & 厌 & & & \\
\hline 1 & & Os & 102 & 7 & 2 & 90 & 48 & 水平 & 37 & - \\
\hline 2 & & $O \delta$ & 94 & 7 & 2 & 57 & 55 & 水汭 & $4 才$ & 謧戊 \\
\hline 3 & 炑: & 08 & 113 & 8 & 3 & 57 & 57 & 水平 & $5 才$ & - \\
\hline 4 & 岩 & $0 \delta$ & 118 & 9 & 4 & 38 & 37 & 濑侹 & 4 - & 柽庭 \\
\hline 5 & $川$ & $\mathrm{O}^{\circ}$ & 122 & 10 & 4 & 50 & $73 !$ & 漸傾 & $4 \gamma$ & 柽度 \\
\hline 6 & 蛓 & Os & 115 & 10 & 4 & 85 & 73 & 水平 & 37 & 高度 \\
\hline 7 & 近 & 09 & 117 & 9 & 4 & 55 & 55 & 水平 & 5 才 & - \\
\hline 8 & 黑 & 0 웅 & 103 & 9 & 4 & 47 & 55 & 水平 & $9 才$ & - \\
\hline 9 & 瓷正 & 09 & 100 & 9 & 4 & 58 & 58 & 水轨 & 57 & - \\
\hline 10 & 富 & $0 \AA$ & 103 & 8 & 2 & 50 & 57 & 漸偭 & 6月 & 軽侅 \\
\hline 11 & 毁 & $0 \delta$ & 113 & 7 & 2 & 63 & 63 & 漸傾 & 6才 & 高度 \\
\hline 12 & 国 & Os & 108 & 8 & 3 & 22 & 17 & 急蘏 & $7 才$ & - \\
\hline 13 & 今人 & $\bigcirc\{$ & 86 & 8 & 3 & 50 & 45 & 水平 & $2 x$ & 简发 \\
\hline 14 & & $0 \%$ & 111 & 11 & 5 & 53 & 53 & 水平 & {$\left[\begin{array}{ll}1 & -7 \\
6 & \text { 月 }\end{array}\right.$} & 高度 \\
\hline 15 & & 08 & 82 & 11 & 5 & 50 & 50 & 水玶 & 4 水 & - \\
\hline .6 & & ) & 89 & 11 & 5 & 50 & 60 & 漱能 & 5 扰 & 垹慢 \\
\hline 17 & itj & $0 \delta$ & 112 & 7 & 2 & $68 \downarrow$ & 70 & 濑䚀 & $\begin{array}{ll}2 & 7 \\
6 & \text { 月 }\end{array}$ & 㗬情 \\
\hline 18 & 公 & $O 5$ & 108 & 9 & 4 & 43 & 63 & 山玨 & $2 x$ & 间庭 \\
\hline 19 & $i^{f}$ & 08 & 95 & 11 & 5 & 48 & 47 & 漸偛 & $4 才$ & 軽度 \\
\hline
\end{tabular}

稪正指導の效果は一進一退といら状態を繰返しながら も僅かずつで山あるが進歩と示した，又，との際補㥁器 を燆正指導の補助的手段として朋いかなりの効果を諗め た(第9表)。

\section{第 5 章 WISC 知能診断検查の成精}

WISC 知能幆断検查を入級前と入級後の 2 回にわた つて行い得た6名の児童について，言語性及び研作性知 能检查の成績を检討し，更にそれらのプロフイール的考 察を行つた。㭘査は風山県中央児童相談所において行つ た。检查成績を第 10 表に示す。

次比6名の児童の評価点を平均し，それを知能プロフ イールとして示寸（第5 图).

WISC 知能検查の評価点はO〜20末でに分布してお り，その平均は10である。

先つ゚気がつくことは，初回，次回検查とも言語性知能 指数が動作性知能指数に此して著しく低いことである。 これはこれらの児童が多少上も言語刺激の少い生活琮境 で生肖したためであり，難德児の特徽を示すものと云え る.

次に，次回娭査のうが初回唡查より言語性及び動作性 知能指数ともに滈くなつて括り，特信言語性知能指数に 扣いて渚しい。これは難聴学級で適切な数育を受け，䓂 語束激が增大してきたためと洘点られる。

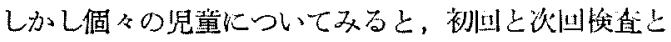

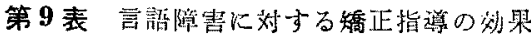

\begin{tabular}{|c|c|c|c|c|c|c|c|c|c|c|c|}
\hline \multirow[t]{2}{*}{ No. } & \multirow{2}{*}{$\begin{array}{l}\text { It } \\
\text { 名 }\end{array}$} & \multirow[t]{2}{*}{ I.Q. } & \multicolumn{2}{|c|}{$\begin{array}{c}\text { 入 } \\
\text { 般 } \\
\text { 時 }\end{array}$} & \multicolumn{2}{|c|}{ 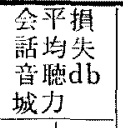 } & \multirow{2}{*}{$\begin{array}{l}\text { 酸 } \\
\text { 力 } \\
\text { 望 }\end{array}$} & \multirow{2}{*}{ 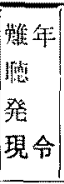 } & \multirow{2}{*}{ 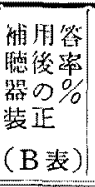 } & \multirow[t]{2}{*}{ 帚語陪筈 } & \multirow{2}{*}{$\begin{array}{l}\text { 矯正指尊の刘果 } \\
\text { (正碓に発音可能と) } \\
\text { なつた語音 }\end{array}$} \\
\hline & & & 年 & & 右 & 左 & & & & & \\
\hline 1 & $\begin{array}{c}\text { 山O } \\
\delta\end{array}$ & 94 & 7 & 2 & 57 & 55 & 水平 & $4 才$ & 78 & $\begin{array}{l}\text { サ行, 心行 } \rightarrow \text { 力行, ザ行, シャ, } \\
シ \pm, ~\end{array}$ & 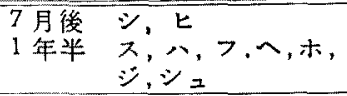 \\
\hline 2 & $\begin{array}{c}\text { 高O } \\
\hat{\delta}\end{array}$ & 115 & 10 & 4) & 85 & 73 & 水平 & $3 才$ & 72 & 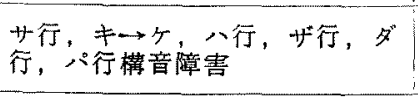 & 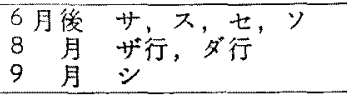 \\
\hline 3 & 身O & 113 & 7 & 2 & 63 & 63 & 洀傾 & $6 才$ & 88 & $\begin{array}{l}\text { サ行一努音化椯音障害 } \\
\text { 全般に発語不明瞭 }\end{array}$ & 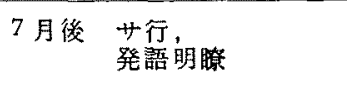 \\
\hline 4 & $\frac{1}{30}$ & 86 & 8 & 3 & 50 & 45 & 水玻 & $2 x$ & 42 & 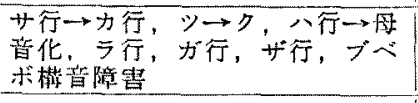 & 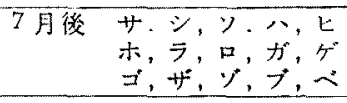 \\
\hline 5 & $\underset{\delta}{\text { ko }}$ & 111 & 11 & 5 & 53 & 53 & 水平 & $\begin{array}{l}1 \text { 才 } \\
6 \text { 月 }\end{array}$ & 66 & $\begin{array}{l}\text { サ行 一タ行, ガ行，ザ行，ダ行 } \\
\text { 模㕷障慧 }\end{array}$ & 7 月後 $カ ゙, コ$ \\
\hline 6 & 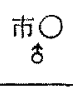 & 112 & 7 & 2 & 681 & $70 \downarrow$ & 激傾 & $\begin{array}{l}2 \text { - } \\
6 \text { 月 }\end{array}$ & 80 & 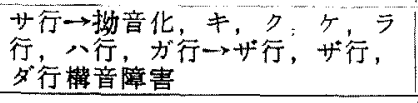 & 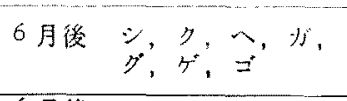 \\
\hline 7 & $\begin{array}{c}\text { 松O } \\
\delta\end{array}$ & 108 & 9 & 4 & 43 & 63 & 山些 & $2 才$ & 82 & 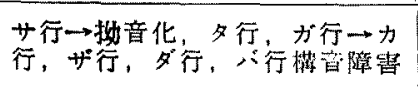 & 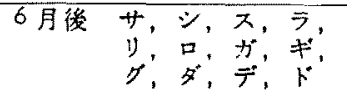 \\
\hline
\end{tabular}


第 10 表 WISC 知能駗断枱查の成䋊

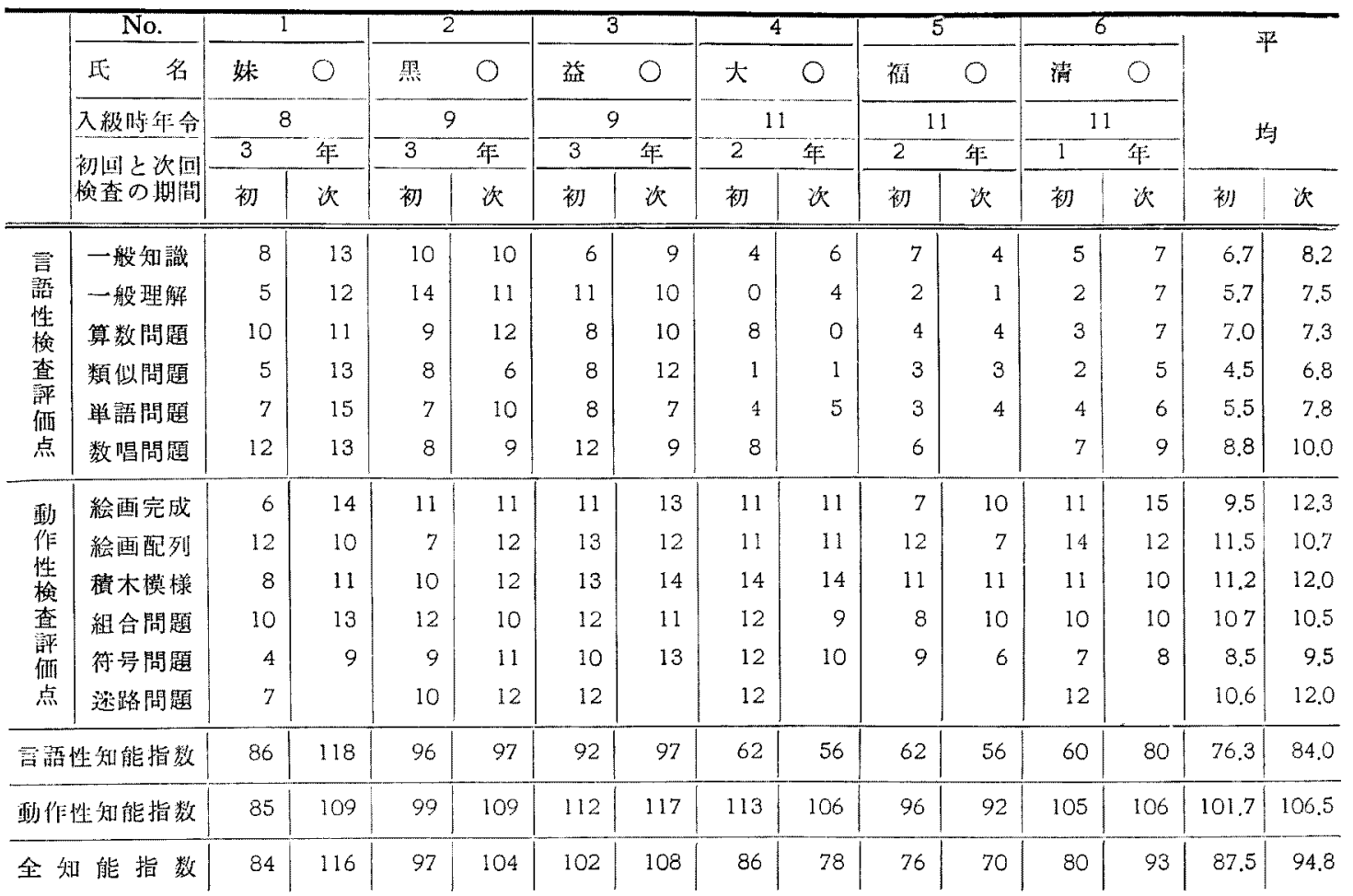

第5图 知能ブロフイール(脏均)

01234567891011121314151617181920
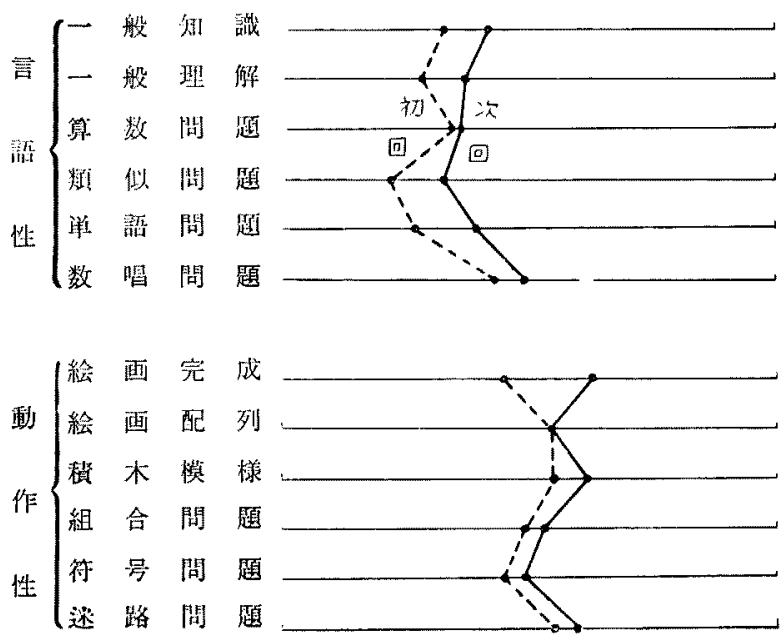

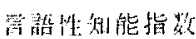

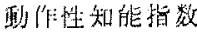

企虭能指妓

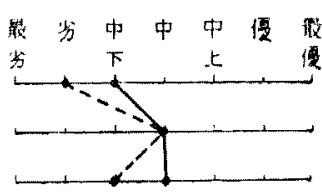

の間の知能指数の变化も栐々であつたので，支れ ぞれの児童の知能ブロフイールを3つのダループ に分けて考祭した。

先ぶ，A グループの No. I と6の児童では次 国检楂の言語性知能指数の问上が特に省明であつ た (第6囯).

B グループの No. 2 と3の照童では初回検查 で卙に平场值に近い值を示して扣り，次回検查で

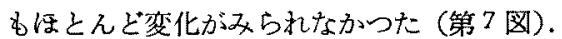

C グループの No. 4 と5の児童では逆に次回 検售の力方言語性，動作性知能指数ともにいくら か低下している. No. 4 の児童では補㯖器茭用後 の正答率が 66\%で非常に覀かつたのが原因と考 えられ，No. 5 の照童では補㯖器装用後の正管婇 が $98 \%$ で非常に良いにもかかわらず，元来の知 能指数が腎がたためにかかる現象が生じたもの と考光られる(第 8 图)。

次に昭和 29 年 7 月から 32 壬12月までに㴊川

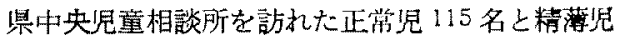
113 名の WISC 知能検查の評価点を平均し知能 


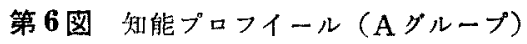

(点線が初回，䒠綵が次回検查成鼠）

No. 1

No. 6

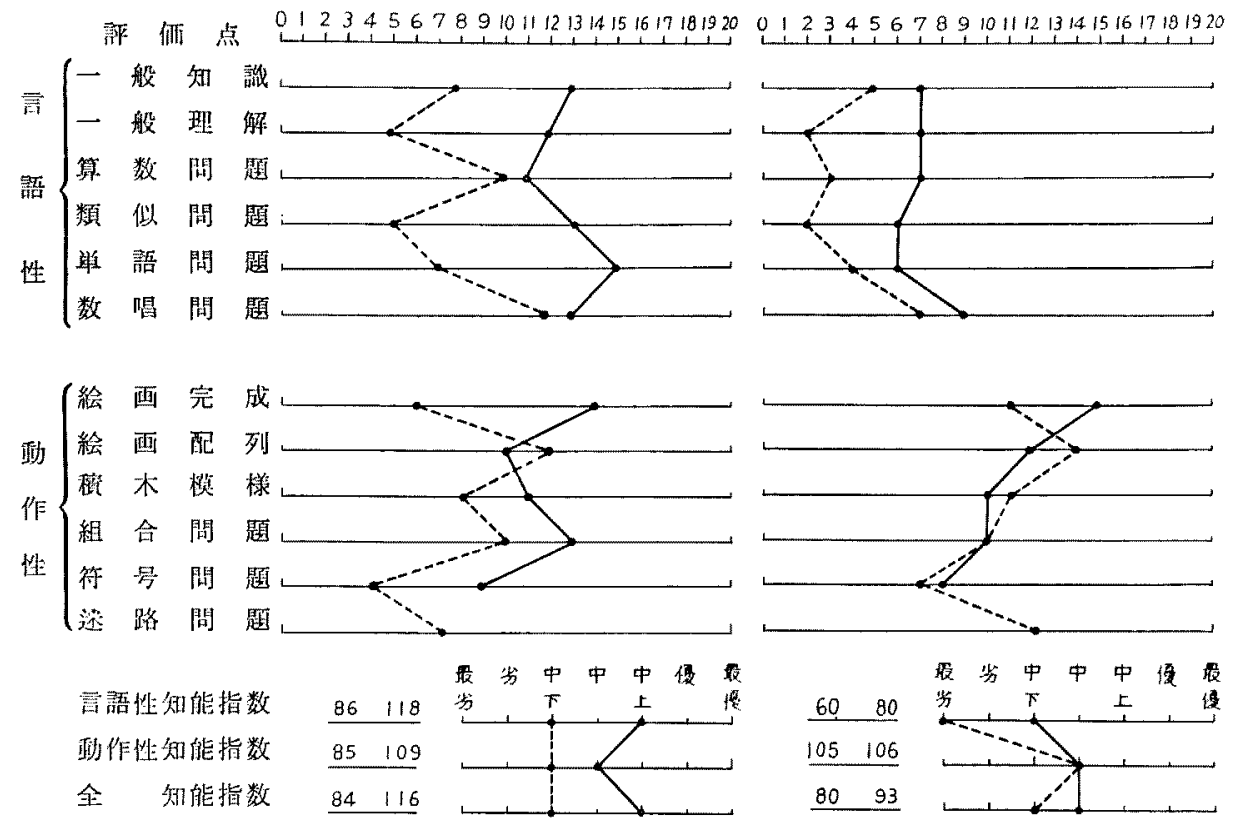

第7图 知能プロフイール(Bグループ)

(点線が初回，実線が次回梌查成转)

No. 2

No. 3

誹 洒 点 0123456789101112131415161718192001234567891011121314151617181920
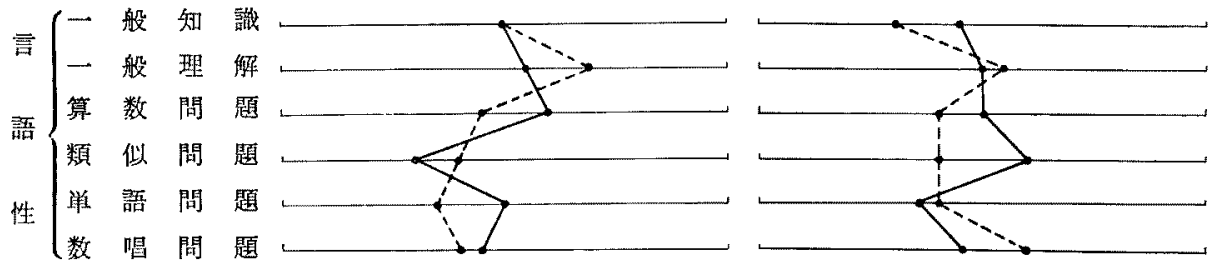

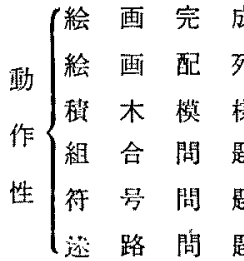

带語性知能指数

重作性知能指数

全 媢能指数
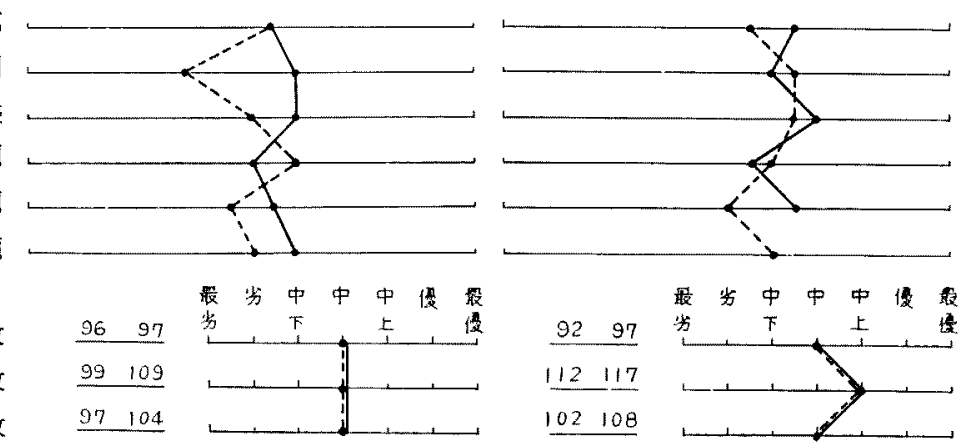
第 8 图 知能プロフイール (Cグループ)

(点線が初回, 实線が次回検查成繶)

No. 4

No. 5

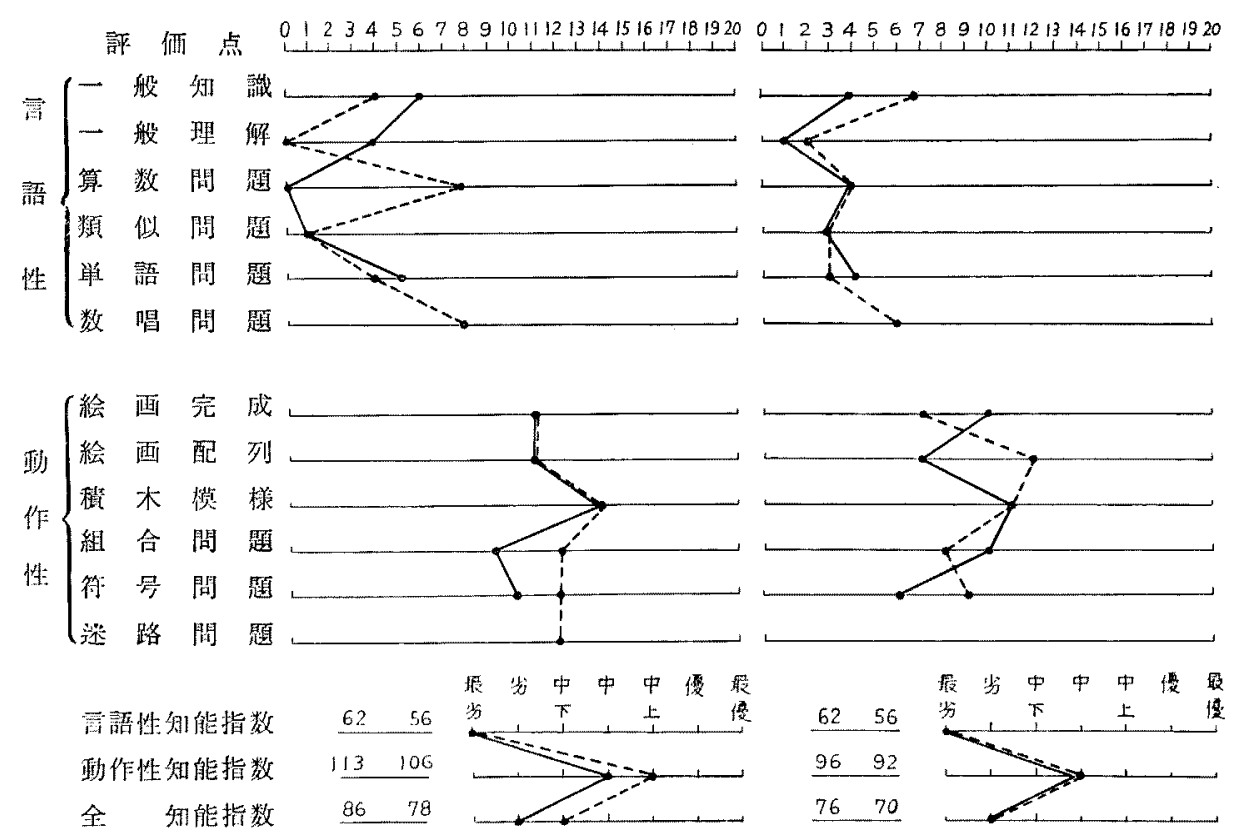

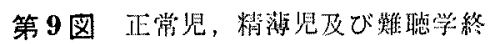
児童の知能プロフイールの比校

01234567891011121314151617181920

部倾点
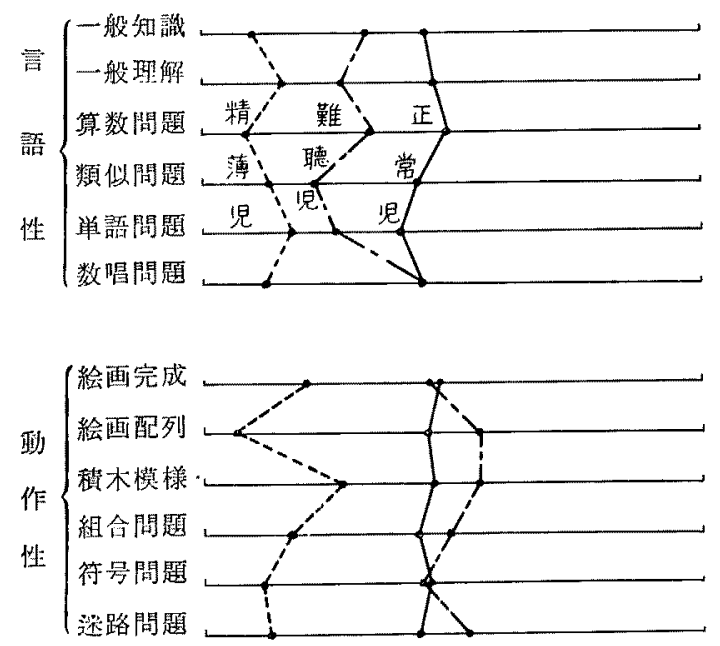

プロフイールとして表わし，これを難聴学級児童の初回 検查の知能プロフイール（皮均）と比較してみた（第 9 区).
即ら，精薄児は言棓性，何作性检查ともに評洒点が低 々，且，変動が大きい。これに対し，難聴罗は言語性検 查の評価点が低く，恋動が大きいが，動作性の評価点で は精薄児に比して高く平均值に近い值を示している。し かし，変㗢证常胃に比してやや大きい。

又, 豈語性检查のプロフイールを比皎すると，難㯖児 と精薄児とでは全く対照的であり，難聴思で比較的高い 評価点を示す問題が精薄児では比較的低く，逆に，難聴 昌で比較的低小ものが精薄児では比較的高くなつてお り，特に一般理解，算数問題，類似問題，数喝問題で著 明である。

\section{第 6 章 考按ならびに難㯖学級適応， 不適応見童についての考察}

従来，感音系難聴は伝音系難聴に比較して，一般に補 㴔器による補聴效果を余り期待でさないとされていた が，はとんどが感音系高度難聴である難聴学級照童につ いて，有意了音節語音表を用いて梌查した結果，かなり 良好な補聴効果を認め，特に，累加現象を認めた児童に おいても，補聴器装用に際して正しい指導を順次注入す ることによつて，補聴効果を良好ならしめることができ た. 
次に，読話についてみると，詰話単独でもかなりの效

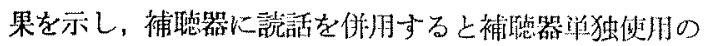
場合の效果を更に高めることがわからた。

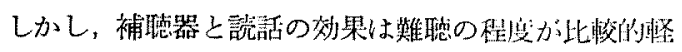
度でも I.Q.が低い児童では瑟いことがわかった。 又， 一般に高音域の成分を多く含む語音（たとえばサ行至）

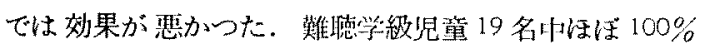
に近い効果を示したものは6名に過ぎなかた。をこ で、難㯖見童に対する教青では, 補㯖器上読話の外に， 視覚に訴兄る教青を重視する必要があることがわかつ た.

陶口，伊原む国立万らセンター外来を訪れた 40db以 上の感音性蜼聴者 100 名について検笪した結果, 補聴器 と䛃話の併用によつて良い効果を得たと報告している。

補聴器装用の年令に関して，Guilder は補媤器の䧶用 と aural rehabilitationは3〜4才で行うのが良いと 報告しているが，我々の場合でも感音系踓㯖が疑われる

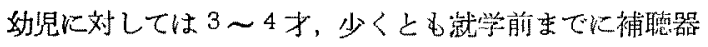
と読話の訓練を適当な施設と指導者の下で受け，その後 に難䏇学級一入級すれば，教育效果がー層高まるるの上 考えている. 叉，これらの高度感音系難聴児では将来難 聴の進行する可能性があり，この意味に㸝いてもできる だけ早期に補聡器の訓練をしておくことが重要である。

難聴の進行に関して, Brockmann は13名の delayed progressive neural hypacusis の小児での調查から，4 才から7 才の時期に聴力が腎化する傾向を認め，Kinneyは8才から11才までの神経性蜼聴胃 461名につい て4年半の锥祭の結果 16 名に, Cornell は8 8 耳中 13 耳に, Osborn は112耳中 24 耳に難聴の進行を認めた。 しかし，Barr は700名の感音系高度難聴児中 1 名子難 聴の進行を認めなかつたと述へててる，我々の難聴学教 児童についてみると, 補聴器装用後, 難聴の進行を自覚

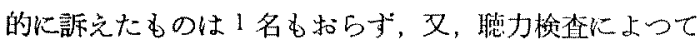
も2名 3 耳に軽度の進行を認めたに過ぎなからた。松井 は100名の補聴器常用者について調べ, 補聴器蔆用によ つて難聴の進行を疑わしめたものは1名のみであつたと 報告している.

学業成績については， 2 年余を経渦した 9 名の䙺望で はすべてに向上が認められたが，個々の冒童では難德の 高度のもの，補埴効果の悪いものに向上の度合が少な く，なかんつく，I.Q.の低いものに打いてその傾向が 著明であつたのは当然であつた。

以上の寺轧から，難悖学級入級胃童を選ぶ際に，知能
挨查の結果を慎重に取报つて，正带知能を有する昌童の みを入級させないと，いたずらに教師に負担をかけるの みで教育の苏が挙らない恐れがある。

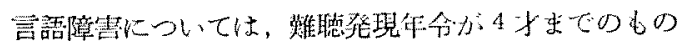

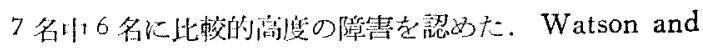
Tolan は高度の衈力陡害をきたした時，成人では2〜3

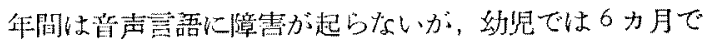

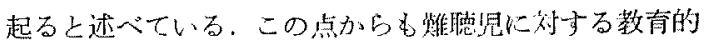
措置はできるたけ早期に始めるべきでする。

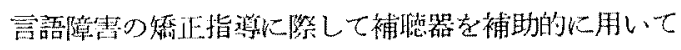
效柴を認めたが, Fowler も補倰器が言語の矯正に役立 つことを述べている。

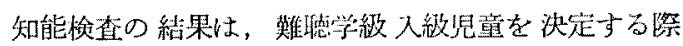
に, 聪力検查の結果と共にもつとも重要な条件となるも

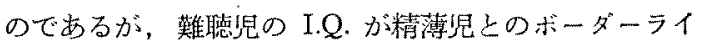
ンにある場合が多く，知能が正常であるか否かを判定す ることはなかながずかしい問題である、沢は小学校1 年から中学校 3 年末での 1,634 名について WISC 知能 検查法に上る知能の発達の研究を行い，小学校 $1 \sim 2$ 年 では全体的知能水準の橴纺に関保なく，動作性知能指数 がいつも言語性知能指数を上迴って括り，小学校 $3 〜 4$ 年と中学校の普通児以下ではこの差が接近し，小学校 5 〜6年の簀秀㸺之中学校の普通児以上では言語性知能指 数の方が動作性 知能指数より侲つていると報告してい る。即ち，一般に知能の発達に扣ける㝘語性知能と動 作性知能との関係は小学校 3〜4年, 即ち9〜10才まで

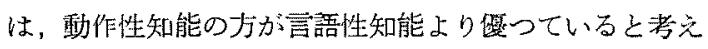
られる、従つて，難僡学級入級胃童を選ふ際に，9〜10 才以下の年令の児童では，動作性知能指数が平均值を示 していても必ずしも全㑣的知能が正労であるとは限ら ず，低い場合もあることを考㽞しておく必要がある。

そこで，難聴学級児童に WISC 知能恰查を入級前と 大級後の 2 回にわたつて行い，その成縝からこの問題に ついて考察を加克てみた，その絬果，CグループのNo. 4 と5 の児童では，入級前の検查での動作性知能指数が 113 上96で平均值を示していたにもか加からず，入級 後の検査での言語性知能指数が入級前上り向上せず，共 に56と低下した：これらはその尖例を示しているもの上

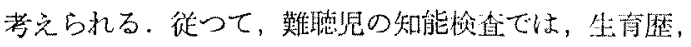
両親との問燮などその児盖の心理学的背景を充分参考に し，検查に際しては检查と被检昌との親和性を密沉する ことが重要である。

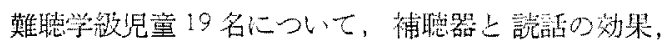


第 11 表 難㯖学级適応，不適応について

\begin{tabular}{|c|c|c|c|c|c|c|c|c|c|c|c|c|c|c|c|}
\hline \multirow{2}{*}{ No. } & \multirow{2}{*}{ 代 名 } & \multirow{2}{*}{ 性生年月日 } & \multicolumn{2}{|c|}{ 入級時 } & \multirow{2}{*}{ I.Q. } & \multicolumn{2}{|c|}{$\begin{array}{r}\mathrm{db} \\
\mathrm{db}\end{array}$} & \multirow{2}{*}{ 難衈型 } & \multirow{2}{*}{ 踾力型 } & \multirow{2}{*}{ 補䁖效果 } & \multirow{2}{*}{$\begin{array}{l}\text { 読話 } \\
\text { 效果 }\end{array}$} & \multirow{2}{*}{$\mid \begin{array}{ll}\text { 学業成鼤 } \\
0\end{array}$} & \multirow{2}{*}{$\begin{array}{l}\text { 带語 } \\
\text { 障害 }\end{array}$} & \multirow{2}{*}{$\mid \begin{array}{l}\text { 矯正指尊 } \\
0 \text { 效 }\end{array}$} & \multirow{2}{*}{ 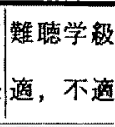 } \\
\hline & & & $\begin{array}{l}\text { 年 } \\
\text { 命 } \\
\end{array}$ & $\begin{array}{l}\text { 学 } \\
\text { 年 }\end{array}$ & & 右 & 左 & & & & & & & & \\
\hline \multicolumn{2}{|c|}{ 35年隻入級 } & & & & & & & & & & & & & & \\
\hline 1 & 尾 $\bigcirc$ & s 27.12 .31 & 7 & 2 & 102 & $90 i$ & 48 & 感音 & 水平 & 良 & 良 & 最 良 & & & 最 邀 \\
\hline 2 & 山 0 & \$ 27.11 .29 & 7 & 2 & 94 & 57 & 55 & 感音 & 水平 & 中p不良 & 不良 & 不 庭 & 简度 & やp不郎 & 不 遵 \\
\hline 3 & 姝 0 & $\$ 26.11 .30$ & 8 & 3 & 113 & 57 & 57 & 感音 & 水平 & 良 & 良 & 最 良 & & & 最 遥 \\
\hline 4 & 岩 $\bigcirc$ & \$ 26.2 .26 & 9 & 4 & 119 & 38 & 37 & 混合 & 漸傾 & 最 㝗 & 良 & 最 良 & 整度 & 良 & 娨 適 \\
\hline 5 & 0 & क $25.2,22$ & 10 & 4 & 122 & 50 & $73:$ & 感音 & 澌傾 & 最 良 & 良 & 摱 良 & 埾䛋: & 良 & 最 適 \\
\hline 6 & 高 0 & o 24.6 .30 & 10 & 4 & 115 & 85 & 73 & 感音 & 水平 & 不 良 & 最良 & やゃ不良 & 高度 & や中不祀 & 中户不邀 \\
\hline 7 & 近 0 & ㅇ 25. 5.10 & 9 & 4 & 117 & 55 & 55 & 感音 & 水平 & 最 良 & 最良 & 最 良 & & & 最 適 \\
\hline 8 & 0 & ㅇ 25.5 .11 & 9 & 4 & 103 & 47 & 55 & 感音 & 水平 & やゃ不息 & 最良 & 良 & & & 適 \\
\hline 9 & 益 0 & ㅇ 27.7 .2 & 9 & 4 & 100 & 58 & 58 & 混合 & 水平 & 良 & 最良 & 良 & & & 適 \\
\hline \multicolumn{2}{|c|}{36 年度入釉 } & & & & & & & & & & & & & & \\
\hline 10 & 富 $\bigcirc$ & o 27.12 .13 & 8 & 2 & 103 & 50 & 57 & 感音 & 濑傾 & 良 & 不良 & 艮 & 軽度 & 良 & 適 \\
\hline 11 & 鳥 0 & o 28.12 .15 & 7 & 2 & 113 & 63 & 63 & 感音 & 澵傾 & 最是 & 不良 & 良 & 高度 & やp不良 & 適 \\
\hline 12 & 国 0 & f 27.6 .18 & 8 & 3 & 108 & 22 & 17 & 感音 & 急薄 & 最 良 & 不良 & 最 良 & & & 適 \\
\hline 13 & 0 & क 27.10 .13 & 8 & 3 & 86 & 50 & 45 & 混合 & 水平 & 不 良 & 不良 & 不 良 & 高度 & 中p不良 & 不 適 \\
\hline 14 & 0 & क 24.11 .10 & 11 & 5 & 111 & 53 & 53 & 感音 & 水平 & やや不良 & 不良 & 中p不良 & 高度 & pp不良 & やや不適 \\
\hline 15 & 0 & 우 24.11 .12 & 11 & 5 & 82 & 50 & 50 & 感音 & 水平 & 最 良 & 底 & やや不良 & & & 中や不適 \\
\hline 16 & 長○川 & \$ 25.1 .29 & 11 & 5 & 89 & 50 & 60 & 感音 & 濑傧 & 良 & 不良 & 良 & 柽度 & 主 & 適 \\
\hline \multicolumn{2}{|c|}{ 37年度入級 } & & & & & & & & & & & & & & \\
\hline 17 & 市 0 & \$ 29.8.8 & 7 & 2 & 112 & $68:$ & $70 \downarrow$ & 感音 & 漸傾 & やや不良 & 不良 & 主 & 高度 & や不良 & 適 \\
\hline 18 & 0 & f 27.4 .20 & 9 & 4 & 108 & 43 & 63 & 混合 & 山 & やや不良 & 最息 & やゃ不良 & 高度 & やp不良 & 適 \\
\hline 19 & 清 0 & o 25.5 .16 & 11 & 5 & 95 & 48 & 47 & 感音 & 漸筫 & 良 & 良 & 最 良 & 軽度 & 良 & 最 適 \\
\hline
\end{tabular}

学業成績，言語障害の矯正指導の效果を検討し，難聴学 級児童として適応であつたか，不適心であつたかを判定 した結果，14名が適応であり，5名は不適応であること がわからた 第11 表).

不適応の 5 名について検討すると，難聴が高度である ことが原因となつたものが1名，I.Q.が低いのが原因 となつたものが 4 名であつた。難㯖が比較的高度の児童 でも I.Q.が镸れているるのでは成果が挙つて扣り，逆 K，難聴が此較的軽度の罗童でも I.Q. の少るものでは 成果が挙つて括らないとがかからた。この事実から， 難聴学級入級児を決定する際には，知能の面を特に重視 する必要があることが方かつた。

\section{第 7 章 結 語}

昭和 35 年 4 月，岡山市立内山下小学校に 難䏇学級を 開設して 2 年余を経過した今，この間，心理学上の問 題, 補聴器と読話の効果, 学業成績の向上の度合, 言語 障害の燆正という諸問題と取組んできたが，一応の成果 を得たので報告した。
しかし，今回の難聴学級ではテストケースとしての胃 童も含まれて招り，一部の児童では必ずしも良い成果を 示さなからたものるあつたので，この原因について検討 してみた。

1) 補聴器と読話の効果では, 補聴器単独使用で, 有 意3音節語音表（B）を朋いた場合，正答率が平均 79.6 $\%$, 補聴器と読話の併用で平均 $83.4 \%$ の良好な効果を 示した，難聴学級胃童 19 名中 15 名が感音系雖聴である が，補聴器と読話を適切に指導与れば担当効果があるこ とがわかつた。

2）学業成績では，2 年余を释過した9名の児童のす

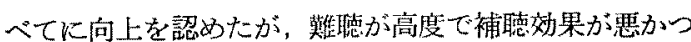
たもの1名，I.Q. が低く，補聴器上読話の効果が悪か つたもの1名，補㯖器之読話の奻果は良かつたが I.Q. が低かつたもの2 名の 4 名では成績が劳ぱしくなかつ た。

3) 䒠語障害で恃，19名中7名に比較的高度の障害 を認め，7名中 6 名は言語の発達のもつとも盛んな 4 才 


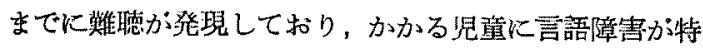

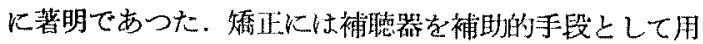
い好結果を認めた。 I.Q.の劣る児童では稫正の效果が 恐かつた。

4）難㯖児に対する知能检㮅では，ての㬰施と判定の 上で非常に困難な場合がある，蜼德学級奣童に WISC 和能検查を入級前と入級後の 2 回にわたつて施行し，言 語性検查, 動作性㭘查, 知能プロフイールの面から, 難

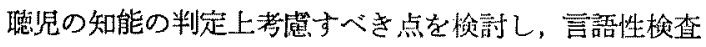
では低い值を示すが，そのプロフイールに精薄昆とは異 なつた特幑があり，動作性検查で正常值を示すといら特 微を提えたが，てれでるな㧩題があることについて述 ヘた.

以上総括してみると，德力損失が $60 \mathrm{db}$ 以上の高度難 聴の㜔童でも知能が正常であればかなりの成果を認め， 聴力損失が $60 \mathrm{db}$ 以下の竞でも知能が少れば余り成 果が举らず, 結局，19名中 14 名が難媤学級に適応であ り，5名が不適応であることがわからた。そして，この らら4名は知能が劣ることが原因と考えられた。

即ら，難聴学級に該当する胃童の条件として，恥力損 失は 45〜60db の範国であることと共に，知能が正常で あるといらことがここに結論つけられた。

\section{留考文献}

1) 高原：難聴学叙の設立について, 耳展，3登：

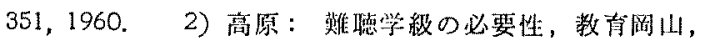

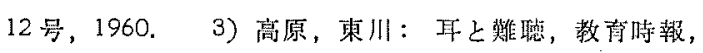
130 号, 1960.4) 高原, 東川, 伏見, 田村: 学査德 力選別㭘查並びに対策についての諸問題，治療 42 萢： 153, 1960 . 5) 高原, 東川：学童の難聴について, 学校保健研究，18号：2,1960.6) 堀口，伊原：数

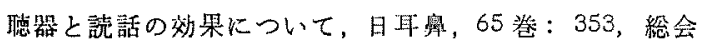

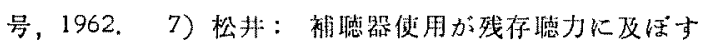

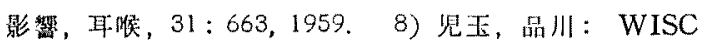

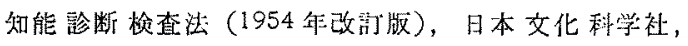

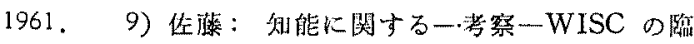

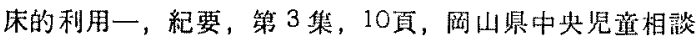
所, 1957. 10) 沢：WISC に上る知能発造，教肖 心理, 4 巻, 4 号, 252頁, 1959, 11) Watson, L.A. and Tolan, T.: Hearing Tests and Hearing Instruments, The Williams \& Wilkins Company (Balt. imore), 1949. 12) Geiger, J.C., Rodin, F.H. \& Chase, B.A.: The Problem of The Hard of Hearing School Child, Arch. of Pediatrics 56: 605, 1939.
13) Gordon, B.: Hearing and Hearing Aids, Laryngoscope $52: 143,1942$. 14) Holmgren, L.: Hearing Tests and Hearing Aids, Acta Oto-Laryng. Suppl. 34, 1939. 15) Davis, H., Hudgins, C.V., Marquis, R.J., Nichols, R.H., Peterson, G.E., Ross, D.A. and Stevens, S.S.: The Selection of Hearing Aids, Laryngoscope 56:85, 1946. 16) Fowler. E.P.: The Value of Individual Hearing Aids for Hard of Hearing Children in Public Schools, Laryngoscope, $56: 26,1946$. 17) First International Conference on Audiology: Acta Oto-Laryng. Suppl. 76, 1949. 18) Hirsh, I.J.: Hearng Aids, Ann. of Otol. Rhin. \& Laryng. 60: 1033, 1951. Wedenberg, E.: Auditory Training of Severely Hard of Hearing Pre-school Children, Acta OtoLaryng. Suppl. 110, $1954 . \quad 20)$ Guilford, F.R.: The Otologist and The Hearing Aid, Arch. of Otolaryng. 61:9, $1955 . \quad$ 21) Barr, B.: Nonorganic Hearing Problem in School Children, Acta OtoLaryng. 52: 337, 1960. 22) Brockman, S.J.: An Exploratory Investigation of Delayed Progressive Neural Hypacusis in Children, Arch. Otolaryng. 70: 340, 1959. 23) Kinney, C.E.: Hearing Impairments in Children, Laryngoscope 63: 220, 1953.

24) Strensen, K.: Hardness of Hearing in School Children, A Study of Schooling and The Etiology of Hearing Impairment among The Pupils of $A$ Danish Hearing School now and 10 years ago, Acta Oto-Laryng. Suppl. 140, 1958.

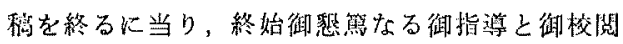

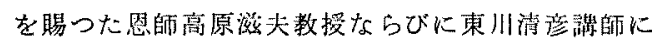

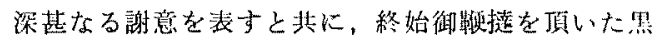
住静之助教授，小會㼁郎詶師ならびに教室舅濖兄，

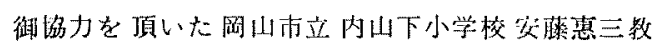

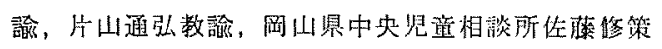
判定課長に感謝いたします。

本論交の要旨は，昭和35年第 2 回中国四国合同地 方会，昭和36年第82回中国地方会，炤和37年第7回 日本オージオロジー学会, 第9回日本学校保位等会 総会及び第7 回日本音声言浯医学会に扣いて演述し た.

（原稆到着 $=$ 昭和 38.6.17日） 